\title{
A Sensory-Labeled Line for Cold: TRPM8-Expressing Sensory Neurons Define the Cellular Basis for Cold, Cold Pain, and Cooling-Mediated Analgesia
}

\author{
Wendy M. Knowlton, ${ }^{1,2}$ Radhika Palkar, ${ }^{1,2}$ Erika K. Lippoldt, ${ }^{1,3}$ Daniel D. McCoy, ${ }^{1,4}$ Farhan Baluch, ${ }^{2}$ Jessica Chen, ${ }^{1}$ \\ and David D. McKemy ${ }^{1,2,3,4}$ \\ ${ }^{1}$ Neurobiology Section, Department of Biological Sciences, ${ }^{2}$ Neuroscience Graduate Program, ${ }^{3}$ Neurobiology Graduate Program, and ${ }^{4}$ Molecular and \\ Computational Biology Graduate Program, University of Southern California, Los Angeles, California 90089
}

\begin{abstract}
Many primary sensory neurons are polymodal, responding to multiple stimulus modalities (chemical, thermal, or mechanical), yet each modality is recognized differently. Although polymodality implies that stimulus encoding occurs in higher centers, such as the spinal cord or brain, recent sensory neuron ablation studies find that behavioral responses to different modalities require distinct subpopulations, suggesting the existence of modality-specific labeled lines at the level of the sensory afferent. Here we provide evidence that neurons expressing TRPM8, a cold- and menthol-gated channel required for normal cold responses in mammals, represents a labeled line solely for cold sensation. We examined the behavioral significance of conditionally ablating TRPM8-expressing neurons in adult mice, finding that, like animals lacking TRPM8 channels (Trpm $8^{-/-}$), animals depleted of TRPM8 neurons ("ablated") are insensitive to cool to painfully cold temperatures. Ablated animals showed little aversion to noxious cold and did not distinguish between cold and a preferred warm temperature, a phenotype more profound than that of $\operatorname{Trpm} 8^{-/-}$mice which exhibit only partial cold-avoidance and -preference behaviors. In addition to acute responses, cold pain associated with inflammation and nerve injury was significantly attenuated in ablated and $\operatorname{Tr} p m 8^{-1-}$ mice. Moreover, cooling-induced analgesia after nerve injury was abolished in both genotypes. Last, heat, mechanical, and proprioceptive behaviors were normal in ablated mice, demonstrating that TRPM8 neurons are dispensable for other somatosensory modalities. Together, these data show that, although some limited cold sensitivity remains in $\operatorname{Trpm} 8^{-/-}$mice, TRPM8 neurons are required for the breadth of behavioral responses evoked by cold temperatures.
\end{abstract}

\section{Introduction}

Sensations, such as touch and pain, are mediated by peripheral sensory neurons through activation of modality-specific sensory receptors (Basbaum et al., 2009; Ma, 2010). For temperature, ion channels of the transient receptor potential (TRP) family function as molecular thermo-detectors, providing the receptor potential that initiates signaling to the CNS (Jordt et al., 2003). Unlike the diversity of heat-sensitive TRPV channels, the preponderance of data suggests that TRPM8, the receptor for menthol (the cooling ingredient in mint), functions as the primary mammalian detector of cold (McCoy et al., 2011). TRPM8 channels activate at temperatures below $\sim 25^{\circ} \mathrm{C}$, with currents increasing in magnitude as temperatures decrease (McKemy et al.,

Received April 19, 2012; revised Nov. 27, 2012; accepted Dec. 13, 2012

Author contributions: W.M.K. and D.D.McK. designed research; W.M.K., R.P., E.K.L., D.D.McC., F.B., J.C., and D.D.McK. performed research; W.M.K. and D.D.McK. contributed unpublished reagents/analytic tools; W.M.K., R.P., E.K.L., D.D.McC., F.B., J.C., and D.D.McK. analyzed data; W.M.K. and D.D.McK. wrote the paper.

This study was supported by National Institutes of Health Grants NS054069 and NS078530 (D.D.McK.). We thank C.P. Ko for assistance with rotarod and grip strength assays, C. Stucky and S. Garrison for assistance with the dynamic stroke assay, R. Lang for the DTR-GFP construct, Y. Takashima, K. Renduchintala, R. Romanu, and C. Messinger for histology assistance, and J. Teng for assistance with behavior quantification.

Correspondence should be addressed to Dr. David D. McKemy, 3641 Watt Way, Hedco Neuroscience Building 228, University of Southern California, Los Angeles, CA 90089. E-mail: mckemy@usc.edu.

DOI:10.1523/JNEUROSCI.1943-12.2013

Copyright $\odot 2013$ the authors $\quad 0270-6474 / 13 / 332837-12 \$ 15.00 / 0$
2002). Behaviorally, mice lacking TRPM8 channels fail to distinguish warm from cool and poorly avoid noxious cold (Bautista et al., 2007; Colburn et al., 2007; Dhaka et al., 2007; Knowlton et al., 2010). Moreover, cold allodynia (pain caused by innocuous stimuli) associated with inflammatory and neuropathic injury is diminished in these animals (Colburn et al., 2007; Knowlton et al., 2011). Thus, because of its prominent role in cold sensation, TRPM8 and the neurons expressing this receptor are attractive targets in the study of cold and cold pain transduction.

Most sensory neurons are polymodal because they are activated by multiple stimulus modalities (Perl, 1996; Cain et al., 2001), properties suggesting that modality discrimination does not occur in the afferent itself but in higher-order structures (Perl, 2007). Consistent with this view, genetic ablation or silencing of neurons expressing the voltage-gated sodium channel Nav1.8 attenuated thermal, mechanical, and inflammatory pain in mice (Abrahamsen et al., 2008; Liu et al., 2010). However, ablation of polymodal neurons expressing the heat-gated channel TRPV1 diminished thermal pain without altering mechanosensation, whereas ablation of a separate population of nonpeptidergic neurons attenuated mechanical pain with no effect on thermal behaviors (Cavanaugh et al., 2009; Mishra and Hoon, 2010; Mishra et al., 2011). These latter results suggest that sensory discrimination does occur, at least in part, at the level of the 
sensory afferent and that the polymodality inherent in these neurons may not translate to stimulus coding.

Like many classes of sensory nerve fibers, those that are cold sensitive are polymodal. For example, mechanosensitive A $\delta$ and C fibers innervating both hairy and glabrous skin are cold sensitive (Simone and Kajander, 1996, 1997; Cain et al., 2001). Similarly, a cohort of menthol-sensitive neurons respond to capsaicin in vitro (McKemy et al., 2002; Viana et al., 2002; Xing et al., 2006; HjerlingLeffler et al., 2007), results consistent with the expression of TRPV1 in a subset of TRPM8 neurons (Takashima et al., 2007; Dhaka et al., 2008). However, it is unclear whether this heterogeneity is relevant in coding of somatic stimuli. Here we selectively ablated TRPM8 neurons in vivo, finding that ablated animals are insensitive to both innocuous and noxious cold, show attenuated cold hypersensitivity after injury, and display a loss of cold analgesia after injury. Ablated mice show normal heat sensation, mechanosensation, and proprioception, results suggesting that TRPM8 afferents represent a "labeled line" for cold sensation.

\section{Materials and Methods}

Trpm $8{ }^{\text {DTR }}$ mice and TRPM8 neuron ablation. All experiments were approved by the University of Southern California (USC) Institutional Animal Care and Use Committee and performed in accordance with the recommendations of the International Association for the Study of Pain and with the National Institutes of Health Guide for the Care and Use of Laboratory Animals. The Trpm $8^{D T R}$ line of transgenic mice was generated as described previously (Takashima et al., 2007). Briefly, a $\operatorname{trpm} 8$ bacterial artificial chromosome (BAC) clone $(553 \mathrm{H} 3$ of the RPCI.22 BAC library; Invitrogen) was modified by homologous recombination, targeting the simian diphtheria toxin receptor (DTR) transgene [a gift from Dr. R. Lang, Cincinnati Children's Hospital Medical Center, Cincinnati, OH (Jung et al., 2002)] to sequences corresponding to the second coding exon in the trpm8 gene. DNA sequences flanking this site were PCR amplified with PfuUltra HF polymerase (Stratagene) and subcloned into the pLD53.SCA-E-B shuttle vector (a gift from N. Heintz, The Rockefeller University, New York, NY) in which the green fluorescent protein (GFP) cassette was replaced with DTR. Shuttle vector DNA was electroporated into electrocompetent bacteria, and cells in which the transgene was correctly targeted were selected as described previously (Takashima et al., 2007). Modified BAC clones were screened by PCR, and $T r p m 8^{D T R}-\mathrm{BAC}$ DNA was purified and injected into the pronucleus of fertilized ova at the USC Transgenic Core Facility as described previously (Takashima et al., 2007). Transgenic founder mice were identified by PCR and backcrossed into the C57BL/6 strain out to more than four generations. Animals were maintained on a $12 \mathrm{~h}$ light/dark cycle and provided access to food and water ad libitum.

Two consecutive diphtheria toxin (DTx) intraperitoneal injections (50 $\mu \mathrm{g} / \mathrm{kg}$ in normal saline; List Biological Laboratories; Sigma) were administered $3 \mathrm{~d}$ apart to both transgenic mice and their control littermates aged $\geq 8$ weeks. All behavioral tests were conducted using mice of either sex at least $21 \mathrm{~d}$ after initial injection and were performed during the animals' light cycle. All animals were handled extensively before the commencement of behavioral testing and acclimated to the testing room. Animals were housed in their home cages immediately before and after testing and were prehabituated to the behavioral apparatus as appropriate. For most assays, responses were video recorded and later quantified by an experimenter blind to genotype. All results were analyzed using one-way ANOVA tests, followed by Bonferroni's and Tukey's HSD post hoc analyses (Origin graphing software), and all data are graphed as means \pm SEM.

Histochemistry. Immunolabeling was performed on dorsal root (DRG) and trigeminal (TG) ganglia and lumbar spinal cords from transgenic mice as described previously (Takashima et al., 2007). Primary antibodies were diluted in a working solution (1\% Triton X-100 in PBS). The antibodies and dilutions used in this study included the following: 1:2000 rabbit anti-GFP (A-11122; Life Technologies), 1:500 chicken anti-GFP (GFP-1020; Aves Labs), 1:500 mouse anti-Nav1.8 (75-166; Neuromab), and 1:1000 rabbit anti-human PGP9.5 (AB1761; Millipore). Labeled sections were incubated overnight at $4^{\circ} \mathrm{C}$ with primary antibodies, washed, and then incubated $1 \mathrm{~h}$ at room temperature with secondary antibodies conjugated to Alexa Fluor-488 or Alexa Fluor-594 (1:1000; Invitrogen). To detect isolectin $\mathrm{B}_{4}\left(\mathrm{IB}_{4}\right)$ binding, we included 1:2000 Griffonia simplicifolia isolectin GS- $\mathrm{IB}_{4}-$ Alexa Fluor-568 (I-21412; Life Technologies) during secondary antibody incubations. Digital images were acquired on a Carl Zeiss AxoImager Z1 with Apotome attachment, and quantification of overlap between GFP expression and that of other neuronal markers was obtained per field, quantified with NIH ImageJ software, and expressed as percentage overlap with the SEM between fields (Takashima et al., 2007, 2010).

Quantitative PCR and microarray. RNA transcripts were purified from sensory ganglia using the RNAeasy Mini kit (Qiagen). cDNA was made from these extracts from $1 \mu \mathrm{g}$ of RNA using the iScript cDNA synthesis kit (Bio$\mathrm{Rad}$ ) according to the instructions of the manufacturers. Quantitative PCR (qPCR) was performed using a Bio-Rad CFX96 RT-PCR detection system and the SsoFast qPCR kit (Bio-Rad) according to the instructions of the manufacturer. The primers used for TRPM8 transcripts were as follows: $M 8$ forward, 5'-GCTGCCTGAAGAGGAAATTG-3'; M8 reverse, 5' -GCCCAG ATGAAGAGAGCTTG-3'. The reference gene used was GAPDH, amplified with the following primer set: GAPDH forward, $5^{\prime}$-TGTAGACCATGTAG TGAGGTCA-3'; GAPDH reverse, 5'-AGGTCGGTGTGAACGGATTT G-3'. For microarray, total RNA was isolated for control and TRPM8 neuron-ablated mice ( $n=8$ mice per condition) using RNAlater buffer (Qiagen) and then precipitated and purified with the RNeasy Mini kit (Qiagen) with in-column DNA digestion following the instructions of the manufacturer. Microarray analyses comparing control with ablated samples were performed in triplicate and assayed using the GeneChip Mouse Gene 1.0 ST Arrays by the USC/Children's Hospital Los Angeles Affymetrix MicroArray Core Facility.

Acetone evaporative cooling and wet-dog shaking assays. The acetone evaporation assay was performed as described previously (Knowlton et al., 2011). Briefly, mice were acclimated for $15 \mathrm{~min}$ in an elevated chamber with a mesh floor (IITC), a syringe with a piece of rubber tubing attached to the end was filled with acetone, and the plunger was depressed so that a small drop of acetone formed at the tip. The syringe was raised from below, depositing the acetone drop on the paw. Mice were tested with an interstimulation period of 4 min per mouse, alternating paws between stimulations. Responses were video recorded for later quantification by multiple observers blind to the experimental conditions. Behaviors were scored according to the magnitude of the response along the following scale: 0 , no response; 1 , brief lift, sniff, flick, or startle; 2, jumping, paw shaking; 3 , multiple lifts, paw lick; 4, prolonged paw lifting, licking, shaking, or jumping; 5, paw guarding. For wetdog shakes, mice were injected intraperitoneally with $50 \mathrm{mg} / \mathrm{kg}$ body weight of icilin in $1 \%$ Tween 80 , and then the resulting behaviors were video recorded over a $20 \mathrm{~min}$ period.

Hotplate/cold plate assay. Animals were placed on a plate chilled to $0^{\circ} \mathrm{C}$ or heated to either 48 or $52^{\circ} \mathrm{C}$, and then their responses were video recorded. For cold, latencies to forepaw flinching and licking or wringing were later quantified, whereas for heat, latencies to hindpaw shaking or licking were determined. For cold, mice were tested with an extended cutoff time of $2 \mathrm{~min}$, whereas cutoff times for animals tested at 48 and $52^{\circ} \mathrm{C}$ were at 60 and $30 \mathrm{~s}$, respectively.

Two-temperature choice assay. The two-temperature choice test was performed as described previously (Daniels and McKemy, 2010; Knowlton et al., 2010). Briefly, animals were acclimated to the chamber for $5 \mathrm{~min}$ with both plates set to $30^{\circ} \mathrm{C}$. Next the animals were given a choice between the control plate $\left(30^{\circ} \mathrm{C}\right)$ and the test plate, which was set to temperatures ranging from 5 to $50^{\circ} \mathrm{C}$. During this $5 \mathrm{~min}$ testing period, animals were videorecorded from above. Another $30-30^{\circ} \mathrm{C}$ acclimation trial was conducted, and then a final test trial was recorded but with plate temperature orientation reversed. Behavior was quantified from videos using custom software (MouseChaser) written in $\mathrm{C}++$ that analyzed each video frame (30 frames/ s), extracted the position of the mouse, and saved it to a log file. The method for tracking the mouse in the video uses the feature-space-based mean-shift algorithm with color histogram as the feature (Comaniciu et al., 2000). The initial position of the mouse on the first video frame was specified manually by entering the $x$ and $y$ positions of the top-left vertex of a square defining a $50 \times 50$ pixel patch on the mouse body as shown in Figure $4 A$. The red, green, and blue values of each of the $50 \times 50$ pixels in the patch were com- 


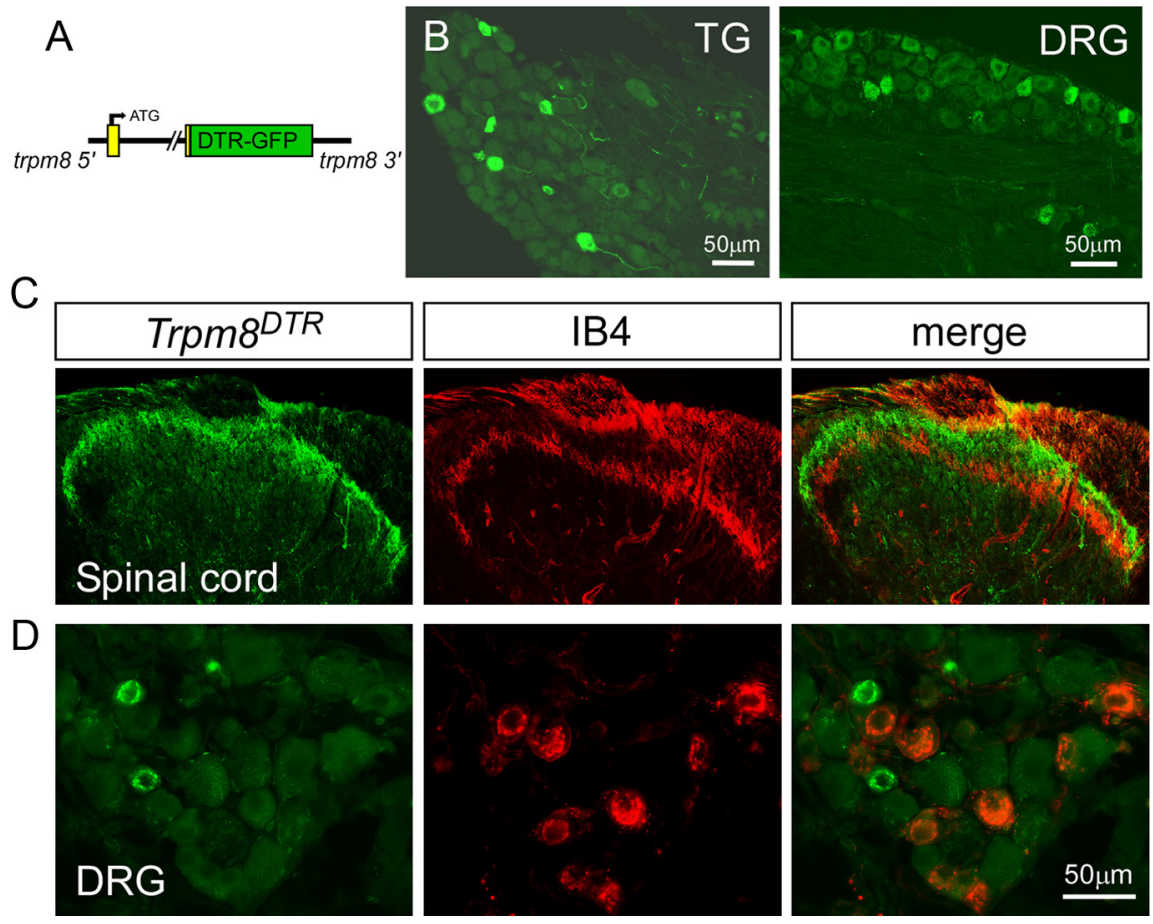

Figure 1. Development of the Trpm $8^{\text {DTR }}$ mouse line. $A$, A complementary DNA transgene for the simian DTR, a GFP fusion protein, was inserted into the trpm $8 \mathrm{BAC}$ clone at sequences corresponding to the second coding exon. $\boldsymbol{B}$, Transgene expression (GFP-expression) in TG and DRG neurons. C, DTR-expressing central projections (green) were localized to the outermost lamina of the dorsal horn of the lumbar spinal cord and did not overlap with those binding to $\mathrm{IB}_{4}$ (red). $D$, Immunolabeling revealed no transgene expression in non-peptidergic neurons that bind $\mathrm{IB}_{4}$.

puted. Each channel's pixels were averaged producing a signature colorbased feature from which subsequent tracking was performed. On each subsequent frame of the video, $50 \times 50$ pixel patches around the starting position were analyzed, and a Euclidean distance measure in feature was computed between each candidate patch (cp) and the target patch (tp) defined in the first frame as follows:

$$
d(\mathrm{cp}, \mathrm{tp})=\sqrt{\left(r_{\mathrm{tp}}-r_{\mathrm{cp}}\right)^{2}+\left(g_{\mathrm{tp}}-g_{\mathrm{cp}}\right)^{2}+\left(b_{\mathrm{tp}}-b_{\mathrm{cp}}\right)^{2}},
$$

where $r_{\mathrm{tp}}$ and $r_{\mathrm{cp}}$ are the mean red pixel values for tp and cp, respectively, and similarly $g$ and $b$ are the mean values for the green and blue channels, respectively. For each iteration, eight nearby patches were analyzed, and the cp with the smallest $d$ measure was chosen as the next location of the center of the mouse. The log file stored by the program contained $x$ and $y$ locations of the mouse over the period of the experiment, which were plotted as a two-dimensional histogram. The two-dimensional space of the image was binned into 5-pixel-wide bins, and each time the mouse center was estimated to be at a particular $x, y$ location, the corresponding bin was incremented. The resulting $x, y$ matrices were normalized to the number of mice in the dataset, and the resulting data were graphed as pseudocolored heat maps to visualize plate location. When tested on the same videos, the software provided comparable results with human observers who measured the time the mouse spent on each plate using a timer.

Hargreaves radiant heat assay. Mice were placed in plastic chambers on a glass surface heated to $32^{\circ} \mathrm{C}$ through which radiant heat was focused on the hindpaw (IITC), and the latency to a paw withdrawal was determined as the average of three trials per animal taken at $10 \mathrm{~min}$ intervals (Hargreaves et al., 1988). To avoid tissue damage, a cutoff latency of $20 \mathrm{~s}$ was used.

Grip-strength test and accelerating rotarod. Animals' grip strength limits were measured using a grip-strength monitor (Chantillon) fitted with a triangular grip wire (Yoo and Ko, 2011). The animal was suspended by the tail in front of the wire and allowed to grip it while the experimenter gently pulled the mouse backward. The maximum force exerted by the mouse at time of release was recorded and averaged over five trials. General coordination was assessed on a rotarod device (Letica Scientific
Instruments) while it was slowly turning at four rotations per minute. When the animal was oriented in the correct direction and stably maintaining its grip on the rod, the device was activated to maximum speed ( $40 \mathrm{rpm}$ ) over $60 \mathrm{~s}$. Time to drop was averaged over five trials.

Dynamic stroke assay. A cotton-tipped swab was puffed up until it was approximately three times its original volume (Garrison et al., 2012). Animals were acclimated on an elevated mesh platform for $15 \mathrm{~min}$, and then the cotton swab was quickly $(<1 \mathrm{~s})$ swiped across the plantar surface of each hindpaw. Removal or shaking of the hindpaw was counted as a positive response, and the percentage of responses were calculated over 10 trials, five per foot, alternating paws, and at least $30 \mathrm{~s}$ apart.

Electronic von Frey. Stimulation with an electronic von Frey apparatus (IITC) was performed as described previously (Knowlton et al., 2011). Briefly, animals were acclimated to an elevated mesh platform for $15 \mathrm{~min}$. The apparatus was fitted with a semi-flexible tip and raised to the plantar surface of the hindpaw. The force at which the mouse removed the paw was measured, and average paw-withdrawal threshold was measured either per mouse or per hindlimb (depending on experiment) from five trials per hindlimb, alternating paws, with 4 min between trials.

Pain models. As described previously (Knowlton et al., 2011), inflammation was induced by injection of $20 \mu \mathrm{l}$ of complete Freund's adjuvant (CFA) into the hindpaw unilaterally. Mice were tested at $2 \mathrm{~d}$ after injection. For neuropathic pain, the chronic constriction injury (CCI) model was used (Bennett and Xie, 1988). Briefly, animals were anesthetized with $5 \%$ isoflurane for induction and then 3\% isoflurane for maintenance. The surface of the right hindlimb was shaved and sterilized. A $2 \mathrm{~cm}$ incision was made in the skin, and the muscles overlaying the sciatic nerve were gently retracted. Three loose ligatures of 6-0 chromic gut were placed around the nerve proximal to the trifurcation site. The muscles were replaced, and the wound was closed with VetBond tissue adhesive (3M) and swabbed with topical antibiotic. Animals were monitored for infection and proper wound healing and were tested on day 7 or later after surgery.

Cooling analgesia. Between 10 and 14 days after CCI surgery, animals were tested for paw-withdrawal thresholds with the electronic von Frey apparatus as described above. Animals were then placed in a shallow ( $\sim 0.5 \mathrm{~cm}$ deep) water bath held at $17^{\circ} \mathrm{C}$ for $5 \mathrm{~min}$. Mice were then retested every 5 min with the electronic von Frey for a total of $60 \mathrm{~min}$.

\section{Results}

\section{Conditional ablation of TRPM8-lineage neurons}

Using a previously developed transgenic strategy (Takashima et al., 2007), we created BAC transgenic mouse lines in which expression of DTR, a fusion with GFP (Saito et al., 2001; Jung et al., 2002), is driven by the $\operatorname{trpm} 8$ transcriptional promoter (Fig. 1A). These animals (referred to as Trpm $8^{D T R}$ mice) displayed normal Mendelian genetics and were phenotypically identical to their nontransgenic littermates. Transgene expression was analyzed by GFP fluorescence and immunoreactivity, and we observed robust labeling in a minor subset of small-diameter neurons within both the DRG and TG [DRG, $11.5 \pm 0.4 \%$ of PGP9.5-labeled neurons $(n=$ 102), $23.1 \pm 0.5 \mu \mathrm{m}$ average diameter $(n=117)$; TG, $16.2 \pm 1.3 \%$ $(n=475), 19.3 \pm 0.2 \mu \mathrm{m}(n=406) ;$ Fig. $1 B]$. As with our previously characterized line of GFP reporter mice $\left[\operatorname{Trpm} 8^{G F P}\right.$, JAX Stock 
\#020650 (The Jackson Laboratory), C57BL/ 6- ${ }^{\mathrm{Tg}}$ (Trpm8-EGFP)1Dmck/J ] that were generated using the same BAC targeting strategy (Takashima et al., 2007, 2010), DTR expression (as determined by GFP immunoreactivity) was observed in axon terminals in the spinal cord dorsal horn in the $\operatorname{Trpm} 8^{D T R}$ line (Fig. 1C). GFP-expressing axons terminated dorsal to non-peptidergic $\mathrm{IB}_{4}$-labeled axons and in the most superficial laminar layers, a termination pattern consistent with thermosensitive afferent fibers. In DRG and TG, GFP expression overlapped with a number of afferent markers but was not found in small-diameter neurons that bind $\mathrm{IB}_{4}$ (Fig. $1 D$ ), data consistent with previous reports on the distribution of TRPM8 expression in neurochemically distinct neurons (Peier et al., 2002; Takashima et al., 2007, 2010; Hayashi et al., 2009).

The simian DTR has a $>10^{5}$ higher affinity for DTx than the rodent ortholog, and systemic injections of subtoxic doses of toxin in mice selectively kills the genetically targeted cell type (Fig. 2A) (Palmiter, 2001; Saito et al., 2001). Thus, mice are allowed to develop normally into adulthood, and cell death is initiated at a specific experimental time point. Following established methods (Chen et al., 2005; Cavanaugh et al., 2009), we developed a DTx injection protocol (two intraperitoneal injections of $50 \mu \mathrm{g} / \mathrm{kg}$ DTx separated by $3 \mathrm{~d}$ ) that led to significant reductions in TRPM8 transcripts in DRG of DTx-injected $\operatorname{Trpm} 8^{D T R}$ animals by $7 \mathrm{~d}$ after the first injection, as determined by qPCR (Fig. 2B; one injection, $12.6 \pm 3.8 \%$ of control; two injections, $0.18 \pm 0.04 \%$ of control, $p<0.0001, n=5)$. Similarly, we observed a complete loss of GFP expression in DRG from DTx-treated Trpm $8^{D T R}$ animals (Fig. 2C,D) but not in DTx-injected $\operatorname{Trpm} 8^{G F P}$ mice (Fig. 2E). Ablation was specific for TRPM8 neurons because there was no significant change in the number of neurons expressing other neurochemical markers. For example, the number of $\mathrm{IB}_{4}$-positive cells in sensory ganglia from DTx-injected $\operatorname{Trp} m 8^{D T R}$ mice versus control animals was unchanged [TG and DRG: $36.0 \pm 1.3 \%$ ablated $(n=4919$ cells $) ; 33.1 \pm 1.6 \%$ control $(n=3927$ cells $), p>0.05$, $n=2-3$ mice each].

To further confirm the specificity of TRPM8 neuron ablation, we used microarrays and compared transcript expression in TG and DRG isolated from DTx-injected $\operatorname{Tr} m m 8^{D T R}$ and control animals (DTx-injected transgene-negative littermates of $\operatorname{Trp} m 8^{D T R}$ mice). Ganglia were dissected and total RNA purified separately for each sample ( $n=8$ each condition). Before combining samples, qPCR was performed on each to ensure that Trpm 8 transcript levels were reduced to $<1 \%(0.8 \pm 0.5 \%)$ in DTx-injected $T r p m 8^{D T R}$ animals. In this screen, TRPM8 transcript expression was reduced 21.8-fold, in addition to other genes whose products are known to express with TRPM8, including cadherin-8, PLC 84 , and TREK-1 (Fig. 2F) (Suzuki et al., 2007; Daniels et al., 2009; Descoeur et al., 2011). Expression of other transcripts known not to colocalize with TRPM8, such as TRPA1 and Mrgprd, were unaffected by TRPM8 neuron ablation (Story et al., 2003; Zylka et al., 2005; Cavanaugh et al., 2009). Thus, using this animal model and the DTx injection protocol described, we set out to determine the necessity of neurons within the TRPM8 lineage in mouse somatosensory behaviors.

\section{Mice lacking TRPM8 neurons are insensitive to innocuous cool and cold mimetics}

We tested DTx-injected $\operatorname{Tr} p m 8^{D T R}$ mice (termed ablated) and their injected control transgene-negative littermates in a variety of behavioral assays, all performed after a recovery period of greater than 3 weeks after DTx injection to fully resolve cell ablation. In addition, to control for any effects of transgene expression and assess differences in mice lacking TRPM8 neurons to those lacking functional TRPM8 channels $\left(\operatorname{Tr} p m 8^{-/-}\right)$, we also examined un-injected $\operatorname{Tr} p m 8^{D T R}$ mice along with wild-type and $\operatorname{Trpm} 8^{-1-}$ mice in these assays (Bautista et al., 2007; Knowlton et al., 2010). First, we assessed responses to innocuous cool using 


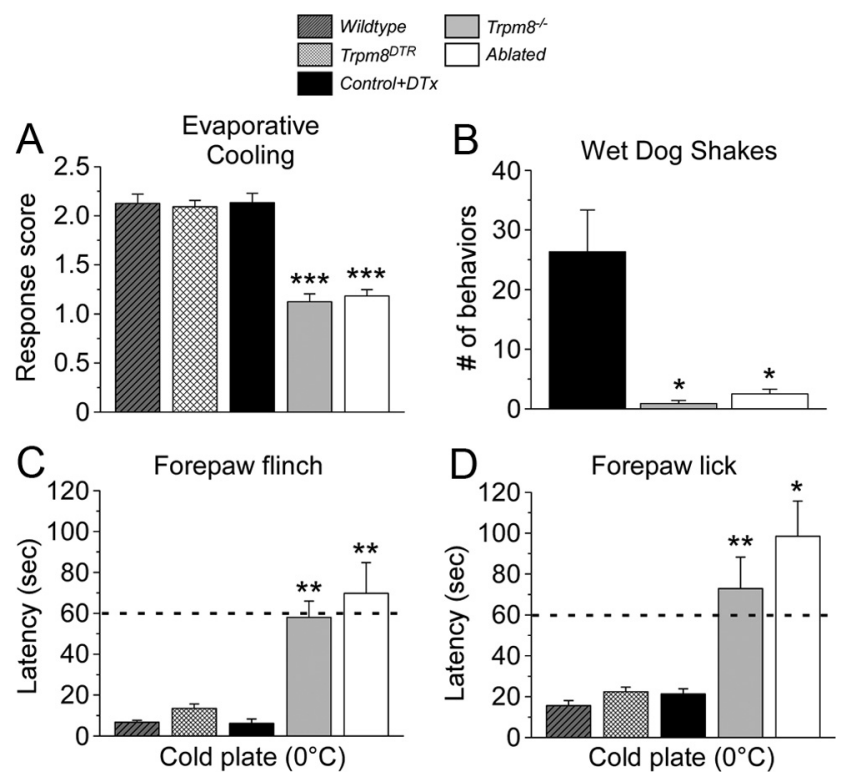

Figure 3. Ablation of TRPM8 afferents abolishes acute cold behaviors. A, Evaporative cooling induced by application of a droplet of acetone to the hindpaw evokes stereotyped behaviors from wild-type, un-injected $\operatorname{Trpm} 8^{\text {DTR }}$, and control mice as determined on a 5-point score scale (see Materials and Methods; Knowlton et al., 2011). The response scores of Trpm $8^{-/-}$and ablated mice were significantly reduced from control to $1.1 \pm 0.1$ and $1.2 \pm 0.1$ ( $n=12$, $\left.{ }^{* * *} p<0.001\right)$, respectively, and were not different from one another $(p>0.05)$. $\boldsymbol{B}$, Intraperitoneal icilin injections ( $50 \mathrm{mg} / \mathrm{kg}$ body weight) induced robust wet-dog shakes in control but were absent in both $\operatorname{Trpm} 8^{-1-}$ and ablated mice $\left({ }^{*} p<0.05\right.$ each compared with control). The latency to nocifensive flinching $(\boldsymbol{C})$ and licking/wringing $(\boldsymbol{D})$ behaviors of the forepaw when mice were placed on a $0^{\circ} \mathrm{C}$ metal plate was recorded. The average latency to flinch and licks in control mice was $6.2 \pm 2.1$ and $21.3 \pm 2.5$ s, respectively $(n=6)$, and similar to that observed in wild-type and Trpm $8^{\text {DTR }}$ mice $(p>0.05)$. Latencies of $T r p m 8^{-1-}$ and ablated mice were significantly higher compared with control at $58.0 \pm 7.9 \mathrm{~s}(n=10)$ and $69.8 \pm 15.0 \mathrm{~s}(n=10)$ for flinching, respectively, and $72.9 \pm 15.4$ and $98.5 \pm 17.1 \mathrm{~s}$ for licking, respectively $\left({ }^{*} p<\right.$ $\left.0.05,{ }^{* *} p<0.01\right)$. Dashed line marks the standard 60 s cutoff time point.

the acetone evaporative cooling assay, a stimulus applied to the mouse hindpaw that transiently reduces surface skin temperature to $\sim 17^{\circ} \mathrm{C}$ (Bautista et al., 2007; Colburn et al., 2007; Knowlton et al., 2011). Flinch, lick, and guarding behaviors were scored on a 5-point scale, with wild-type and un-injected $\operatorname{Trpm} 8^{D T R}$ mice exhibiting similar scores of $2.1 \pm 0.1$ and $2.1 \pm 0.1$, respectively $(n=8-12$ animals, $p>0.05$; Fig. $3 A$ ), demonstrating that transgene expression had no effect on cold behaviors. DTx injection did not alter cold-induced behaviors because like scores were obtained from control littermates $(2.1 \pm 0.1)$, whereas both Trpm $8^{-1-}$ and ablated animals showed little to no response to acetone $\left(1.1 \pm 0.1 \mathrm{Trpm} 8^{-/-}, 1.2 \pm 0.1\right.$ ablated; $n=8-12, p<$ 0.001 compared with control) (Fig. $3 A$ ). In this assay, a score of 1 indicates a brief lift or sniff of the stimulated paw-responses similar to if a droplet of room temperature water were applied. These data show that response to innocuous cool requires intact TRPM8 afferents, as well as functional TRPM8 channels.

The super-cooling cold-mimetic icilin elicits forceful TRPM8-dependent shaking movements, characterized as wetdog shakes, when given systemically (Wei and Seid, 1983; Colburn et al., 2007; Dhaka et al., 2007), as well as evokes nocifensive flinching behaviors after intraplantar paw injections in the mouse (Knowlton et al., 2010). These behaviors are thought to be attributable to the cooling effects of icilin (Tse and Wei, 1986), and we tested whether the shivering-like behaviors required intact TRPM8 afferents. Injection of icilin into the intraperitoneal cavity of control mice induced $26.3 \pm 7.0(n=6)$ shakes during the 20 min observation period, whereas $\operatorname{Trpm} 8^{-/-}$animals exhibited little to no shivering-like behaviors $(0.9 \pm 0.5$ shakes, $n=$ $8, p<0.05$ compared with control) (Fig. $3 B$ ), as reported previously (Dhaka et al., 2007). Ablation of TRPM8 afferents also abolished icilin-induced wet-dog shakes with the number of behaviors $(2.5 \pm 0.8, n=12, p<0.05$ compared with control) trending higher but not statistically different from $\operatorname{Trpm} 8^{-/-}$ mice $(p>0.05$; Fig. $3 B$ ). Together with the evaporative cooling results, these data show that animals lacking TRPM8-expressing neurons exhibit profound impairments in their ability to acutely respond to cold temperatures and chemical cold mimetics.

\section{Novel assays reveal the necessity of TRPM8 channels and neurons in detecting noxious cold}

One of the great difficulties in assessing noxious cold-evoked behaviors is that rodents are essentially unperturbed when exposed to these temperatures, unlike the robust hindpaw lifting, flinching, and licking behaviors observed when animals are placed on a surface heated above $45^{\circ} \mathrm{C}$. This is most evident with traditional measures of hindpaw response latencies in mice placed on a $0^{\circ} \mathrm{C}$ cold plate ranging from 5 to $200 \mathrm{~s}$ in several independent reports (Bautista et al., 2006, 2007; Colburn et al., 2007; Dhaka et al., 2007). Our analyses observed that wild-type C57BL/6 mice rarely show nocifensive behaviors with their hindpaws under these conditions, generally assuming a posture primarily limiting contact with the cold surface to only the hindpaws (W.M.K., R.P., E.K.L., D.D.McK., unpublished observations). However, additional examination revealed two robust and reproducible behaviors performed by every animal tested, both involving the forepaws. The first presented as a shivering or shaking motion of both forepaws, termed forepaw flinching, which occurred shortly after wild-type animals are placed on the cold surface. This is followed by a second behavior involving a wringing or licking of the forepaw, suggestive of intense irritation.

Thus, we turned our analysis to mouse forepaw behaviors when placed on a $0^{\circ} \mathrm{C}$ cold plate to determine whether ablation of TRPM8 neurons alters responses to noxious cold. In control animals, we observed a latency to forepaw flinch of $6.2 \pm 2.2 \mathrm{~s}$ (Fig. $3 C, n=6)$, similar $(p>0.05)$ to that of wild-type $(6.8 \pm 0.9 \mathrm{~s}, n=$ $8)$ and $\operatorname{Trpm} 8^{D T R}(13.5 \pm 2.2 \mathrm{~s}, n=8)$ mice. In contrast, both $\operatorname{Trpm} 8^{-1-}$ and ablated mice had significantly longer flinch latencies of $58.0 \pm 7.9$ and $69.8 \pm 15.0 \mathrm{~s}$, respectively (Fig. $3 C$; $n=10$, $p<0.01$ compared with control). Similarly, latencies to lick were $15.6 \pm 2.5,22.4 \pm 2.3$, and $21.3 \pm 2.5$ s for wild-type, $\operatorname{Trpm} 8^{D T R}$, and control mice $(n=6-16)$, respectively, and significantly longer in Trpm $8^{-/-}$and ablated animals at $72.0 \pm 15.4(p<0.01$ compared with control) and $98.5 \pm 17.1 \mathrm{~s}(p<0.05$ compared with control), respectively (Fig. $3 D, n=10$ ). It should be noted that cutoff times to limit exposure to such potentially tissuedamaging stimuli are typically near 60 s (Cavanaugh et al., 2009; Mishra et al., 2011), a time exceeded to observe any behavior in $\operatorname{Trpm} 8^{-1-}$ and ablated animals. Therefore, it is unclear whether these animals are responding only after prolonged and profound cooling or to possible tissue damage induced by exposure to noxious cold temperatures. Regardless, the impairment observed in ablated mice compared with control demonstrates these animals' inability to appropriately respond to painfully cold temperatures.

\section{TRPM8 neuron-ablated animals show decreased} cold discrimination

In another test of the necessity of TRPM8 neurons in cold behaviors, we determined whether ablated animals have deficits in temperature discrimination using the two-temperature choice assay 

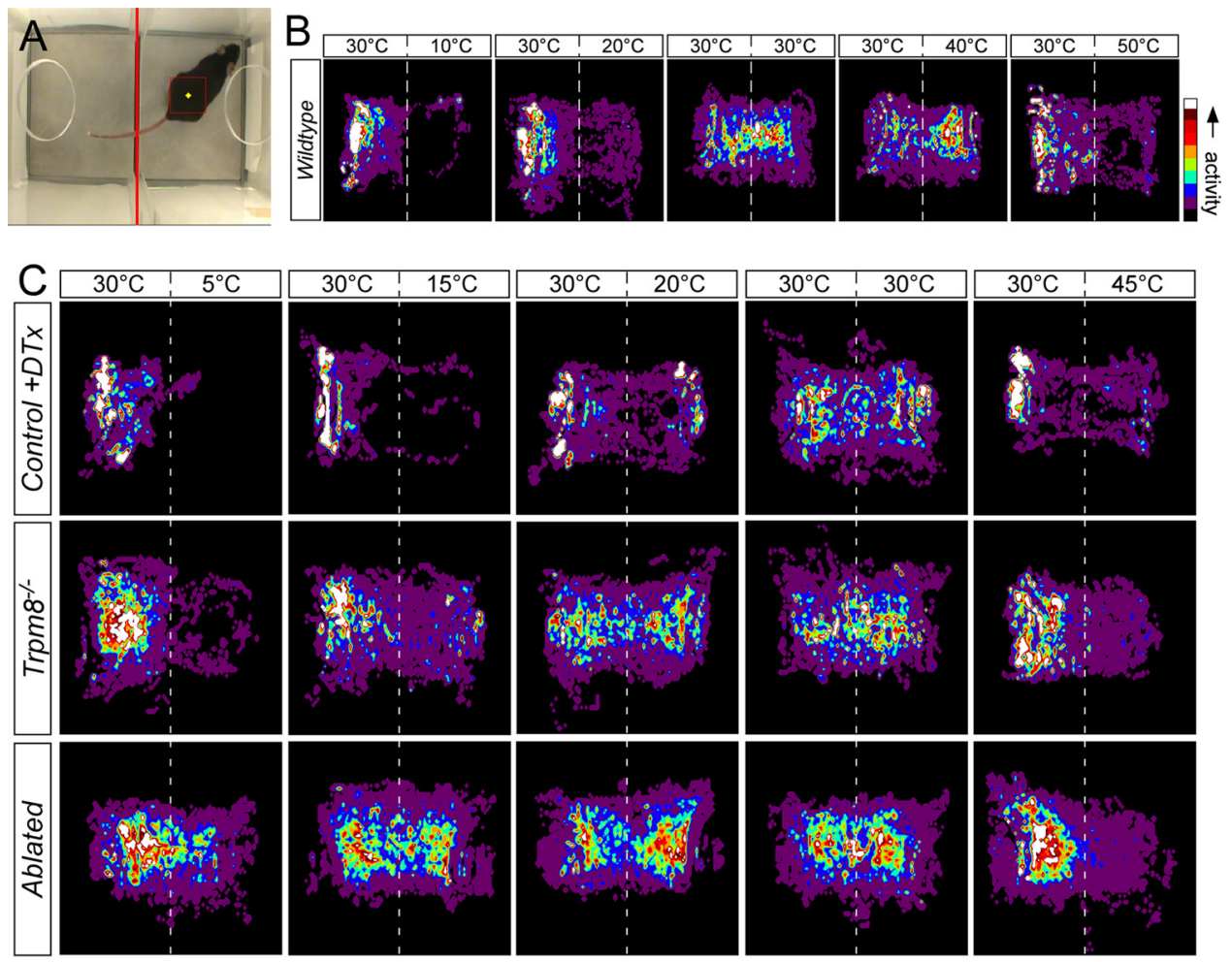

Control $+D T x$

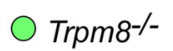

$\Delta$ Ablated
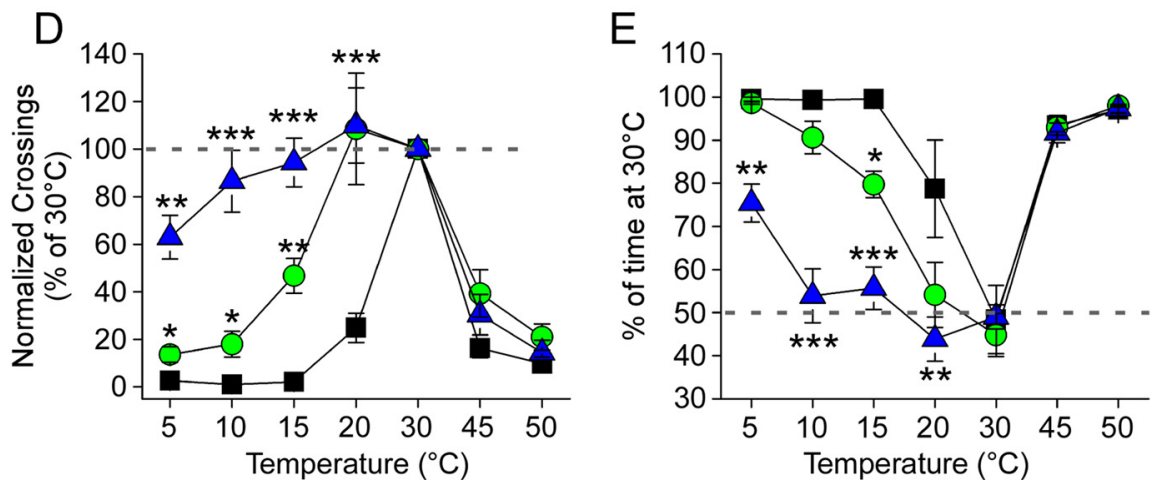

Figure 4. Mouse mobility on the two-temperature choice assay is altered in absence of TRPM8 channels and neurons. $\boldsymbol{A}$, The MouseChaser tracking software was developed to analyze mouse movement on the two-temperature choice assay. Screen capture from software after annotation of video with position of mouse. The red square is an estimate of the mouse's position with the yellow diamond marking the center of which the $x$ and $y$ coordinates are logged over the course of the video. $\boldsymbol{B}$, Movements of wild-type mice in the two-temperature choice chamber, with the control surface held constant at $30^{\circ} \mathrm{C}$ and the test at temperatures from 10 to $50^{\circ} \mathrm{C}$, were monitored over a 5 min period. Pseudocolored exploration plots show qualitatively equal activity on both surfaces set to $30^{\circ} \mathrm{C}$, with reduced movement to and on the test surface as it was either heated or cooled. $\mathrm{C}$, Comparative analysis of mobility from noxious cold ( $5^{\circ} \mathrm{C}$ ) to noxious heat ( $45^{\circ} \mathrm{C}$ ) for control, $\mathrm{Trpm}^{-/-}$, and ablated mice. $\boldsymbol{D}$, Avoidance of the test surface was measured as the number of times the animal crossed between surfaces, with control mice showing decreased mobility as the temperature deviated from $30^{\circ} \mathrm{C}$. Both $\operatorname{Trpm} 8^{-1-}$ and ablated mice avoided noxious heat but, unlike controls, did not avoid 20 versus $30^{\circ} \mathrm{C}\left({ }^{* *} p<0.01, n=6-12\right)$. Trpm $8^{-/-}$mice did avoid cold as temperatures dropped below $20^{\circ} \mathrm{C}$ but not to the same extent as control mice ( ${ }^{*} p<0.05$ ). However, ablated mice showed no avoidance behaviors until test plate temperatures of $5^{\circ} \mathrm{C}$. $\boldsymbol{E}$, Preference for warmth was determined by quantifying the time spent on the $30^{\circ} \mathrm{C}$ surface, with all genotypes showing strong preference for warmth over painful heat ( $p<0.001$ compared with test at $\left.30^{\circ} \mathrm{C}\right)$. Control and $\operatorname{Trpm} 8^{-1-}$ mice showed warm preference at temperatures $\leq 15^{\circ} \mathrm{C}\left(p<0.001\right.$ compared with test at $\left.30^{\circ} \mathrm{C}\right)$, whereas ablated animals showed no preference between 10 and $20^{\circ} \mathrm{C}\left(p>0.05\right.$ compared with test at $\left.30^{\circ} \mathrm{C}\right)$ and moderate preference at $5^{\circ} \mathrm{C}\left(p<0.01\right.$ compared with test at $\left.30^{\circ} \mathrm{C}\right)$. Preference behaviors for ablated mice were different from control and $\operatorname{Trpm} 8^{-/-}$animals at all temperatures below $20^{\circ} \mathrm{C}\left({ }^{* *} p<0.01,{ }^{* * *} p<0.001\right)$.

(Bautista et al., 2007; Colburn et al., 2007; Dhaka et al., 2007; Daniels and McKemy, 2010; Knowlton et al., 2010). Mice were permitted to freely explore two neighboring surfaces, with one set to a preferred temperature of $30^{\circ} \mathrm{C}$ (Moqrich et al., 2005) and the other set to temperatures ranging from 50 to $5^{\circ} \mathrm{C}$. We developed a mouse tracking software system (MouseChaser) to monitor these movements in an unbiased manner (Fig. 4A; see Materials and Methods). Mouse movement was monitored for $5 \mathrm{~min}$, and then averaged activity was plotted as pseudo-colored "heat maps"
( $n=6-16$ animals) when given the choice of $30^{\circ} \mathrm{C}$ or a range of temperatures from 50 to $5^{\circ} \mathrm{C}$. Analysis of wild-type mouse movement demonstrates that animals restricted exploration to the control plate as test plate temperatures diverged to either cold or hot extremes (Fig. 4B). Careful examination of these data showed that wild-type mice appear to avoid noxious cold $\left(10^{\circ} \mathrm{C}\right)$ even more robustly than noxious heat $\left(50^{\circ} \mathrm{C}\right)$. When control, $\operatorname{Trpm} 8^{-/-}$, and ablated mouse movement was analyzed in this manner, we observed similar activity between all genotypes when 
the test plate was at 30 and $45^{\circ} \mathrm{C}$, with all animals showing less activity on the $45^{\circ} \mathrm{C}$ surface (Fig. $4 \mathrm{C}$ ). Comparable behaviors were observed for control animals at $20^{\circ} \mathrm{C}$, with progressively lower activity on the test surface as temperatures advanced toward $5^{\circ} \mathrm{C}$. The activity of $\operatorname{Trpm} 8^{-/-}$and ablated mice on the $20^{\circ} \mathrm{C}$ surface was indistinguishable from that observed at $30^{\circ} \mathrm{C}$, whereas $\operatorname{Trp} m 8^{-/-}$animals did show reduced movements at $5^{\circ} \mathrm{C}$, although not as robust as controls. However, ablated mice showed more activity on the $5^{\circ} \mathrm{C}$ surface than control and $\operatorname{Trpm} 8^{-1-}$ mice, indicating either reduced aversion to this noxious cold stimulus or lessened preference for warmth.

We quantified this behavior as described previously (Knowlton et al., 2010), first examining the number of transitions (crossings) from the control $\left(30^{\circ} \mathrm{C}\right)$ to the test surface, behaviors indicative of thermal avoidance. For example, when the test surface was set to $30^{\circ} \mathrm{C}$, mice of all genotypes freely transitioned between surfaces (Fig. 4D). However, when the test surface is set to $50^{\circ} \mathrm{C}$, a highly noxious heat temperature, control, $\operatorname{Tr} p m 8^{-/-}$, and ablated mice showed significantly reduced mobility and avoided the test surface, demonstrating that mice lacking TRPM8 channels and neurons are able to detect a noxious heat stimulus. Similarly, when the test plate is cooled as little as $10^{\circ} \mathrm{C}$ from the preferred temperature of $30^{\circ} \mathrm{C}$, control animals $(n=6)$ avoided the cold surface with the number of crossings at $20^{\circ} \mathrm{C}$ decreasing to $24.8 \pm 6.1 \%$ of those at $30^{\circ} \mathrm{C}$ (Fig. $4 D, p<0.001$ ). However, both $\operatorname{Tr} p m 8^{-/-}$ $(n=8)$ and ablated $(n=12)$ mice did not discriminate warm from cold with the number of crossings at $108.5 \pm 23.5$ and $109.9 \pm 15.8 \%$, respectively, of those at $30^{\circ} \mathrm{C}$ when the test surface was held at $20^{\circ} \mathrm{C}(p>0.05)$. As the test surface was cooled further, $\operatorname{Trpm} 8^{-/-}$mice did exhibit decreased mobility but still crossed more than control mice, even at noxious cold temperatures $\left(13.6 \pm 3.2 \%\right.$ for $\operatorname{Trpm} 8^{-/-}$and $2.6 \pm 2.6 \%$ for control at $10^{\circ} \mathrm{C}, p<0.05$; Fig. $4 D$ ). However, ablated animals displayed an even greater deficit in cold-avoidance behaviors, crossing at a rate similar to when both plates were at $30^{\circ} \mathrm{C}$ even when the test plate was cooled to $10^{\circ} \mathrm{C}\left(86.5 \pm 13.0 \%\right.$ of $\left.30^{\circ} \mathrm{C}, p=0.3\right)$, and only showed decreased mobility at $5^{\circ} \mathrm{C}(63.0 \pm 9.2 \%$ of the crossings at $30^{\circ} \mathrm{C}, p<0.01$ ), results consistent with the heat map analysis (Fig. 4C).

We also analyzed behaviors in terms of preference for one temperature over another by quantifying the percentage of the recording period that the animal was on the control surface (Bautista et al., 2007; Colburn et al., 2007; Dhaka et al., 2007; Knowlton et al., 2010). When both surfaces were set at $30^{\circ} \mathrm{C}$, animals of all genotypes showed no preference for either surface but did show a strong preference for the control surface when the test plate was heated $\left(45-50^{\circ} \mathrm{C}\right.$; Fig. $\left.4 E\right)$. When the test surface was set to an innocuous cool temperature $\left(20^{\circ} \mathrm{C}\right)$, control animals spent a significant percentage of the 5 min observation period on the control side $(78.7 \pm 11.3 \%$ of the recording period, $p<0.05$; Fig. $4 E$ ), indicating either a strong preference for the warmth or avoidance of the cold, motivations that cannot be differentiated in this type of analysis (Knowlton and McKemy, 2011; McCoy et al., 2011). Furthermore, when the test plate was cooled into the noxious cold range, control mice showed an even more robust preference for warmth $(99.3 \pm 0.6 \%$ when test plate at $10^{\circ} \mathrm{C}, p<0.001$ ). As we and others have shown (Bautista et al., 2007; Colburn et al., 2007; Dhaka et al., 2007; Knowlton et al., 2010), $\operatorname{Trpm} 8^{-1-}$ mice were unable to discriminate between 30 and $20^{\circ} \mathrm{C}$, spending $54.2 \pm 7.5 \%$ of the recording period on the control plate $\left(p<0.001\right.$ vs control at $20^{\circ} \mathrm{C} ; p>0.05$ vs at $\left.30^{\circ} \mathrm{C}\right)$, a behavior that was phenocopied by ablated animals who spent $43.9 \pm 5.0 \%$ of the observation period on the control surface $\left(p<0.001\right.$ vs control at $20^{\circ} \mathrm{C} ; p>0.05$ vs $30^{\circ} \mathrm{C}$; Fig. $\left.4 E\right)$. Thus, consistent with the evaporative cooling assays (Fig. $3 A$ ), mice lacking TRPM8 channels and neurons cannot detect temperatures in the innocuously cool range.

Previous reports, including our own, analyzing preference behaviors have shown that $\operatorname{Trpm} 8^{-1-}$ animals are partial for warmth as temperatures enter into the noxious cold range of below $15^{\circ} \mathrm{C}$ (Bautista et al., 2007; Dhaka et al., 2007; Knowlton et al., 2010). Other cold-detection mechanisms have been suggested to account for this preference for warmth at noxious cold, chief among these the irritant receptor TRPA1, a channel implicated previously in noxious cold detection (Story et al., 2003). However, we have shown that these preference behaviors are retained in mice deficient in both TRPM8 and TRPA1 channels (Knowlton et al., 2010). Thus, it is not clear whether this behavior indicates the existence of TRPM8-independent cold-detection mechanisms at cold extremes or a robust attraction to the warmth that predominates even in the absence of input from cold fibers (Knowlton et al., 2010; McCoy et al., 2011). Here we also observe warm preference in $\operatorname{Trpm} 8^{-/-}$mice at temperatures $\leq 15^{\circ} \mathrm{C}$, with responses similar to control mice at the lowest temperatures tested $[90.6 \pm 3.8 \%(p>0.05)$ and $98.6 \pm 0.3 \%(p>$ $0.05)$ at 10 and $5{ }^{\circ} \mathrm{C}$, respectively]. Moreover, control mice showed similar preference behaviors as wild-type and uninjected $\operatorname{Trpm} 8^{D T R}$ mice (data not shown). However, animals lacking TRPM8 neurons failed to show any preference for warmth at moderately noxious cold temperatures, spending $55.7 \pm 4.9$ and $53.9 \pm 6.2 \%$ of the recording period on the control surface when the test was held at 15 and $10^{\circ} \mathrm{C}$, respectively $\left(p<0.001\right.$ vs control at 15 and $10^{\circ} \mathrm{C} ; p>0.05$ vs $30^{\circ} \mathrm{C}$; Fig. $\left.4 E\right)$. It was not until the test plate was cooled to $5^{\circ} \mathrm{C}$ did we observe warm preference in ablated mice $(75.4 \pm 4.4 \%, p<0.001$ vs ablated at $30^{\circ} \mathrm{C}$ ) but to levels that still were significantly different from behaviors of control or $\operatorname{Trp} m 8^{-/-}$animals at this temperature $(p<0.001)$.

\section{TRPM8 neuron-ablated animals have a selective loss of acute cold behaviors}

We next tested whether TRPM8-expressing neurons contribute to other somatosensory modalities or whether they represent a sensory labeled line for only cold (Ma, 2012). The twotemperature choice assay described above shows that animals lacking TRPM8 neurons can accurately discriminate warmth from noxious heat (Fig. 4). Furthermore, we tested the latency to exhibit a nocifensive response (hindpaw shaking and licking) on a hotplate in ablated and control animals. When placed on a 48 or $52^{\circ} \mathrm{C}$ hotplate, ablated mice responded with latencies of $14.2 \pm$ 1.3 and $8.9 \pm 1.2 \mathrm{~s}(n=12)$, respectively, responses that were not significantly different from those of control animals $(13.5 \pm 0.8 \mathrm{~s}$ at $48^{\circ} \mathrm{C}$ and $8.5 \pm 0.8 \mathrm{~s}$ at $52^{\circ} \mathrm{C}$ ) or the number of other genotypes tested, including wild-type, $\operatorname{Trpm} 8^{-/-}$, and un-injected $\operatorname{Tr} p m 8^{D T R}$ mice $(p>0.05, n=6-12$; Fig. $5 A, B)$. In addition, we observed no difference in latency to paw withdrawal from a radiant heat source in $\operatorname{Trpm} 8^{-/-}$or ablated mice compared with control $(p>0.05$; Fig. $6 C, D)$.

To determine whether TRPM8 neuron ablation altered mechanosensation or proprioception, we tested paw-withdrawal thresholds with the electronic von Frey assay, an indicator of low-threshold mechanical nociception. As with noxious heat, neither control nor ablated animals differed in the force required to induce a paw withdrawal $(6.6 \pm 0.2 \mathrm{~g}$ for control, $6.8 \pm 0.1 \mathrm{~g}$ for ablated), similar to forces that evoked withdrawals in $\operatorname{Tr} p m 8^{-/-}$, wild-type, and un-injected $\operatorname{Tr} p m 8^{D T R}$ mice $(p>0.05$, 


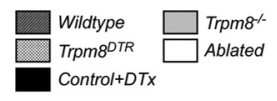

A
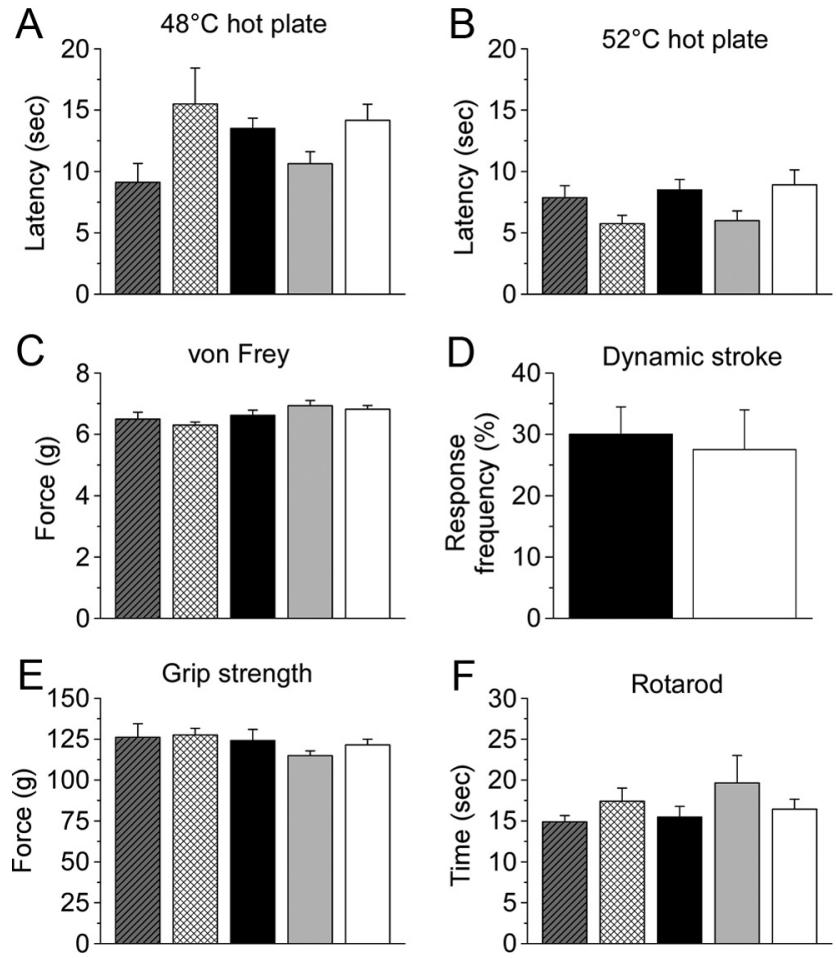

Figure 5. Heat, mechanical, and proprioceptive behaviors do not require TRPM8 neurons. Latencies to hindpaw flinching on a hotplate were the same at $(\boldsymbol{A}) 48^{\circ} \mathrm{C}$ and $(\boldsymbol{B}) 52^{\circ} \mathrm{C}$ in all genotypes tested ( $p>0.05, n=6-12$ ). $C$, Mildly noxious mechanical stimulation of the hindpaw with the electronic von Frey apparatus yielded similar paw-withdrawal thresholds in all genotypes $(n=6-12, p>0.05)$. D, Dynamic stroke of the hindpaw with a puffed-up cotton swab yielded similar response frequencies in both control and ablated mice $(n=8-11, p>$ $0.05)$. $\boldsymbol{E}$, The average maximum grip strengths were similar across all genotypes, as was the latency to drop from an accelerating rotarod $(\boldsymbol{F})(n=6-27, p>0.05)$.

$n=6-12$; Fig. $5 C$ ). To test light mechanosensation, we used the dynamic stroke assay (Garrison et al., 2012), again finding no differences between the responses of control and ablated animals to this stimulus. Ablated animals responded to $27.5 \pm 6.5 \%(n=$ 8 ) of the stimulation trials, with control mice responding to $30 \pm$ $4.5 \%$ of the trials $(p>0.05, n=11$; Fig. $5 D)$. For proprioception and motor coordination, we tested each genotype on the grip strength and accelerating rotarod assays, again finding no differences between ablated animals and the various other genotypes tested (Fig. $5 E, F$ ). Control animals had a maximum grip strength of $124.1 \pm 6.8 \mathrm{~g}$ and a fall latency of $15.5 \pm 1.3 \mathrm{~s}$ in the rotarod assay $(n=6)$, whereas ablated animals had a maximum grip strength of $121.4 \pm 3.5 \mathrm{~g}(p>0.05)$ and a latency to fall of $16.4 \pm$ $1.2 \mathrm{~s}(p>0.05)$ on the rotarod $(n=27)$. Together with the cold behavior results, these data suggest that TRPM8 neurons are primarily dedicated cold sensors. Moreover, although a small subset of TRPV1 neurons are depleted in TRPM8 neuron-ablated animals, these mice retain normal heat sensation. Similarly, cold fibers have been shown to be mechanosensitive in nerve recordings, but TRPM8 afferents are dispensable for normal acute mechanosensation.

\section{Contribution of TRPM8 neurons to cold hypersensitivity}

We next examined inflammatory and neuropathic pain behaviors in control, Trpm $8^{-/-}$, and ablated animals. To test inflam-

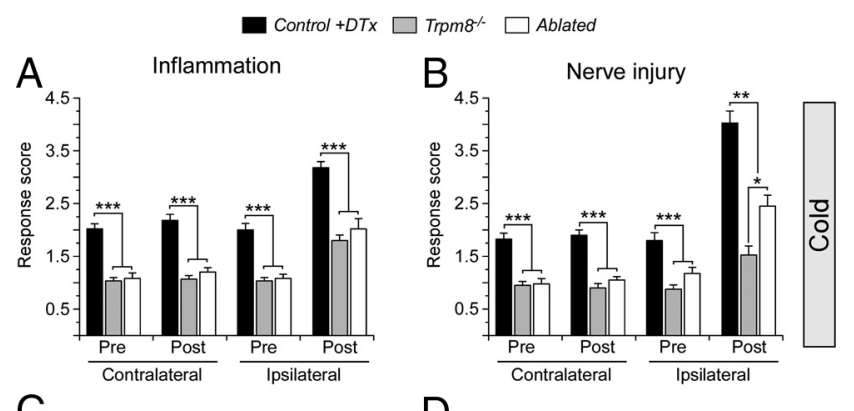

C

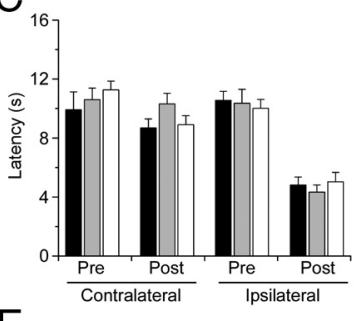

$\mathrm{E}_{8}$
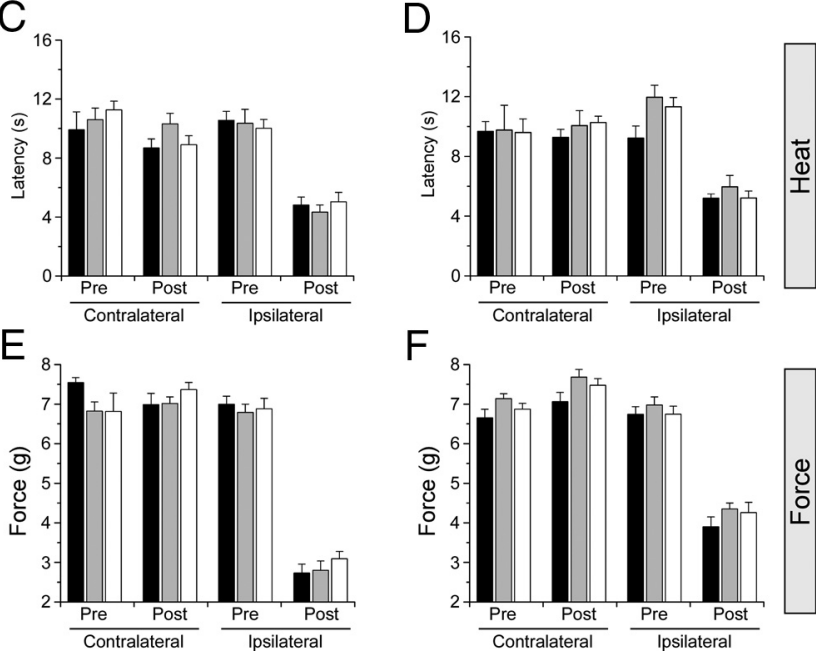

F

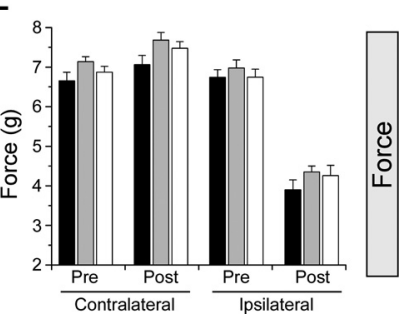

Figure 6. TRPM8 neuron ablation selectively diminishes inflammation- and nerve injuryinduced cold allodynia. $A$, Inflammation significantly increased ipsilateral, but not contralateral, response scores to evaporative cooling in control mice by $2 \mathrm{~d}$ after CFA injection $(n=10)$. Both Trpm $8^{-/-}(n=6)$ and ablated mice $(n=10)$ showed significantly lower sensitization compared with controls $\left({ }^{* * *} p<0.001\right)$ but were significantly increased over baseline and the contralateral side $(p<0.01)$. There were no significant differences in sensitization between Trpm $8^{-1-}$ and ablated mice $(p>0.05)$. B. After induction of irritation to the sciatic nerve $(\mathrm{Cl})$, control mice showed an increase in ipsilateral scores, whereas contralateral scores remained unchanged $(n=8)$. Both Trpm $8^{-1-}$ and ablated mice $(n=8$ each) showed significantly lower sensitization compared with controls and were significantly increased over baseline and the contralateral side $(p<0.01)$. Unlike (FA, ablated mice showed a significant increase in nocifensive behaviors compared with control mice $\left({ }^{*} p<0.05,{ }^{* *} p<0.01,{ }^{* * *} p<\right.$ $0.001)$. In both the $C F A(C)$ and $C C I(D)$ models, the significant $(p<0.001)$ decrease in latencies to hindpaw lift from a radiant heat source were identical between all genotypes tested $(p>$ $0.05)$. Similarly, mechanical thresholds were increased on the ipsilateral side $(p<0.001)$ but were indistinguishable $(p>0.05)$ between all genotypes before and after injury in both pain models $(\boldsymbol{E}, \boldsymbol{F})$.

matory pain, we performed unilateral hindpaw injections of CFA, a condition that induces robust cold allodynia that is primarily dependent on expression of functional TRPM8 channels (Colburn et al., 2007; Knowlton et al., 2011). Using the evaporative cooling assay, we observed a significant increase in cold behaviors in control mice in the inflamed (ipsilateral) paw, with response scores increasing from $2.0 \pm 0.1$ before CFA injection to $3.2 \pm 0.12 \mathrm{~d}$ later $(p<0.01, n=10$; Fig. $6 A)$. In comparison, responses in the un-inflamed (contralateral) paw were unchanged $(2.0 \pm 0.1$ before injection to $2.2 \pm 0.1$ after injection, $p>0.05)$. Interestingly, both $\operatorname{Tr} p m 8^{-/-}(n=6)$ and ablated mice $(n=10)$ also showed significant increases in acetone score from baseline at $2 \mathrm{~d}$ after injection, although responses at both time points were significantly lower than controls. $\operatorname{Trpm} 8^{-/-}$mice increased from $1.0 \pm 0.1$ to $1.8 \pm 0.1$, with ablated similarly increasing from $1.1 \pm 0.1$ to $2.0 \pm 0.2$ (Fig. $6 A, p<0.01$ ), post-injury values that were indistinguishable between these two genotypes $(p=0.4)$. However, both $\operatorname{Tr} p m 8^{-/-}$and ablated mice 


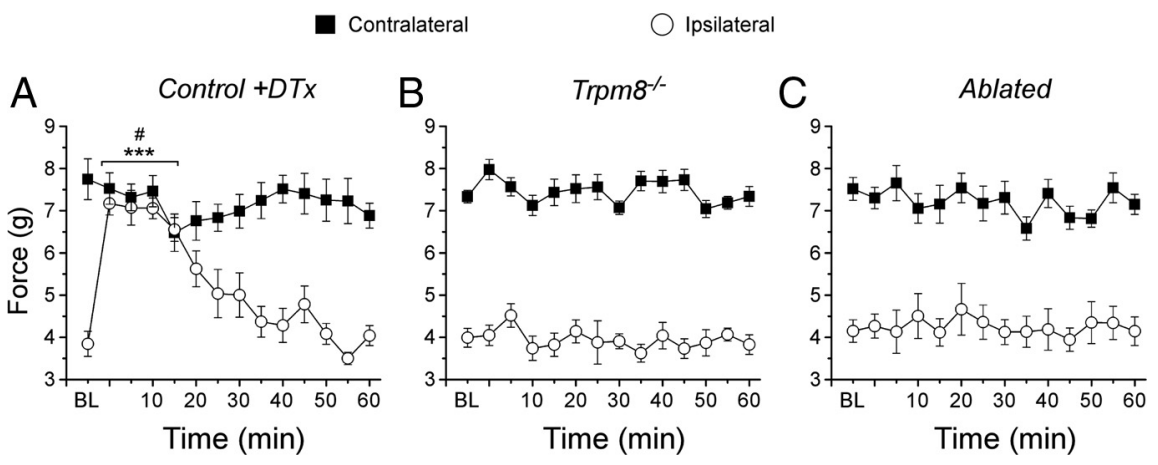

Figure 7. Mice lacking TRPM8 or neurons are deficient in cooling-induced analgesia. $\boldsymbol{A}$, In a neuropathic pain model (CCl), control mice exhibited increased sensitivity to mechanical stimuli that was temporally alleviated by cooling the affected paw $\left(17^{\circ} \mathrm{C}\right.$ for $5 \mathrm{~min}$ ). Before cooling [baseline (BL)], ipsilateral thresholds were significantly lowered from that recorded contralateral ( $p<$ 0.001). After cooling, ipsilateral thresholds were significantly increased over baseline $(3.8 \pm 0.3 \mathrm{~g}$ at baseline compared with $7.1 \pm 0.4 \mathrm{~g}$ at $5 \mathrm{~min}$ after cooling; $\left.{ }^{* * *} p<0.001\right)$ and indistinguishable from contralateral thresholds $(7.7 \pm 0.5 \mathrm{~g}$ at baseline compared with $7.3 \pm 0.3 \mathrm{~g}$ at $5 \mathrm{~min}$ after cooling, $\left.{ }^{\#} p>0.05\right)$. $\operatorname{Trpm} 8^{-/-}(\boldsymbol{B})$ and ablated $(\boldsymbol{C})$ mice showed decreased ipsilateral mechanical thresholds in the $\mathrm{CCl}$ model $(p<0.001)$ similar to controls and were unaffected by cooling.

failed to develop the intense hypersensitivity observed in control mice $(p<0.001)$. This inability of inflammation to induce cold allodynia was not attributable to a general lack of sensitization because there were no differences between the three groups in the development of heat ( $n=5-7$ each genotype, $p>0.05$; Fig. $6 C$ ) or mechanical hypersensitivity $(n=6$ each genotype, $p>0.05$; Fig. 6E).

We also examined neuropathic pain induced by CCI of the sciatic nerve (Bennett and Xie, 1988), a nerve injury model leading to cold allodynia that is also attributed to TRPM8 (Colburn et al., 2007; Knowlton et al., 2011; Su et al., 2011). Similar to inflammation, irritation of the sciatic nerve induced a large increase in nocifensive behaviors to evaporative cooling in control mice $(n=$ 8 ), with response scores increasing from $1.8 \pm 0.1$ before to $4.0 \pm$ 0.2 by 1 week after surgery $(p<0.001$; Fig. $6 B)$. In both $\operatorname{Trpm} 8^{-/-}$and ablated animals $(n=8)$, cold allodynia was significantly muted in the CCI model compared with control but was again increased over baseline measurements or that observed in the contralateral paw $(p<0.05)$. However, unlike the results of inflammation, there was a significant difference in nocifensive responses to cooling between $\operatorname{Trpm} 8^{-/-}$and ablated animals with response scores of $1.5 \pm 0.2$ and $2.5 \pm 0.2$, respectively (Fig. $6 B, p<0.05)$. These results suggest that cold allodynia primarily requires expression of TRPM8 but that ablation of TRPM8expressing afferents only partially suppresses neuropathic cold hypersensitivity. TRPM8 protein levels in rat DRG have been shown to increase after nerve injury (Su et al., 2011). Moreover, TRPM8-like immunoreactivity was observed ectopically in nociceptors that do not express the channel under nonpathological control conditions in the CCI model in rats (Proudfoot et al., 2006). However, we failed to observe TRPM8 expression by qPCR in ipsilateral or contralateral DRG from ablated animals $14 \mathrm{~d}$ after surgery (data not shown), results demonstrating that this phenotype was not attributable to incomplete TRPM8 neuron ablation. Furthermore, heat ( $n=5-7$ each genotype) and mechanical ( $n=6$ each genotype) thresholds were decreased after nerve injury and indistinguishable between mice of all three genotypes $(p>0.05$; Fig. $6 D, F)$.

\section{TRPM8 cells are required for cooling-mediated analgesia} Cooling and menthol are used medicinally to alleviate acute and chronic pain (Bini et al., 1984; Eccles, 1994; Green and McAuliffe,
2000). In a rodent model of neuropathic pain, mild cooling $\left(16-18^{\circ} \mathrm{C}\right)$ produces transient analgesia to mechanical and nociceptive stimuli (Proudfoot et al., 2006; Dhaka et al., 2007). Although these elegant studies strongly implicated TRPM8, the dependence of cooling analgesia on expression of functional TRPM8 channels in chronic pain models was not conclusively determined, nor is it clear whether these effects depend on intact cold afferent signaling. To test this, we used the CCI model of neuropathic pain in control, $\operatorname{Trpm} 8^{-1-}$, and ablated mice and examined mechanical hypersensitivity 7-10 d after surgery. Thresholds for all genotypes were lowered on the ipsilateral side compared with those recorded on the contralateral paw $(n=6-8, p<0.001$; Fig. $7 A-C)$, and there were no significant differences between the three genotypes $(p>0.05)$, consistent with that described previously (Fig. 6F) . To induce cooling analgesia, mice were placed for $5 \mathrm{~min}$ in a thermally controlled water-filled chamber, held at $17^{\circ} \mathrm{C}$, in which the water just covered the animals' paws (Proudfoot et al., 2006). Immediately after cessation of cooling, we measured sensitivity, observing no significant differences $(p>0.05)$ in response thresholds on the contralateral paw in all three genotypes, demonstrating that the cooling had no effect on normal mechanosensation (Fig. $7 A-C$ ). However, in control animals, ipsilateral thresholds were significantly different $(p<0.001)$ from baseline measurements immediately after cooling, changes that were maintained for up to 20 min before returning to baseline by $\sim 40$ min after cooling (Fig. 7A). Moreover, the ipsilateral pawwithdrawal thresholds were not significantly different from contralateral thresholds $(p>0.05$ for the period $0-15 \mathrm{~min}$ after cooling). However, this cooling-mediated analgesia was completely absent in $\operatorname{Trpm} 8^{-/-}$and ablated animals, showing no changes in paw-withdrawal thresholds after cooling, maintaining similar thresholds throughout the course of the experiment $(n=$ 8; Fig. $7 B, C)$. These data confirm previous reports on the involvement of TRPM8 in cooling-induced pain relief (Proudfoot et al., 2006; Dhaka et al., 2007) but show for the first time the absence of analgesia in $\operatorname{Trpm} 8^{-1-}$ mice in a neuropathic pain model, as well as demonstrate that this pain-relief mechanism requires signaling via TRPM8 afferent nerve fibers.

\section{Discussion}

Polymodality of sensory afferents suggests that stimulus encoding does not occur in the afferent itself but is deciphered in higher centers, such as the spinal cord or brain (Perl, 2007; Basbaum et al., 2009). Consistent with this hypothesis, ablation of DRG neurons expressing Nav1.8 led to deficits in mechanical, cold, and inflammatory pain (Abrahamsen et al., 2008). Capsaicinsensitive neurons are also polymodal, responding to both thermal and mechanical stimuli in nerve recordings (Cain et al., 2001). However, chemical ablation of capsaicin-sensitive central projections of DRG neurons causes deficits in painful heat sensitivity but has no effect on mechanical responses (Cavanaugh et al., 2009). Similar results were observed after genetic ablation of neurons within the TRPV1 lineage (McKemy, 2011; Mishra et al., 2011). Furthermore, genetic ablation of neurons expressing the Mas-related G-protein-coupled receptors Mrgprd attenuated 
mechanical pain yet had no effect on thermal behaviors (Cavanaugh et al., 2009). These results imply the presence of socalled labeled lines, at least at the level of the afferent nerve fiber, that exist as nonoverlapping neuronal populations carrying information pertaining to a single somatosensory modality to the CNS (Cavanaugh et al., 2009; Ma, 2010).

Here we provide evidence that, like TRPV1 and Mrgprd-expressing afferents, TRPM8 neurons also represent a labeled line, in this case mediating cold and cold pain. Like many afferent types, TRPM8 neurons are molecularly heterogeneous; however, the functional significance of this heterogeneity is uncertain (Takashima et al., 2007). For example, approximately one-half of these cells are also capsaicinsensitive and express TRPV1 (McKemy et al., 2002; Viana et al., 2002; Babes et al., 2004; Hjerling-Leffler et al., 2007; Takashima et al., 2007, 2010). Thus, subsets of neurons are both heat and cold sensitive, yet the significance of their activation is unknown. We observed no defects in heat sensing in $\operatorname{Tr} p m 8^{D T R}$ mice given DTx, yet only a small fraction of TRPV1-expressing neurons $(\sim 10 \%)$ were ablated in these animals, suggesting that the presence of other intact TRPV1 afferents were likely sufficient to elicit appropriate behaviors. Moreover, in both inflammatory and neuropathic pain models, ablation of TRPM8 neurons had no effect on thermal hyperalgesia. Similarly, many cold-sensitive neurons are also mechanosensitive (Simone and Kajander, 1996, 1997), yet we observed no deficits in acute mechanical responses in ablated mice, nor were there differences in mechanical pain after injury, further supporting the select role of TRPM8 neurons in cold transduction.

TRPM8 is required for multiple forms of cold signaling, including innocuous cool, noxious cold, cold allodynia, and cooling analgesia (Proudfoot et al., 2006; Colburn et al., 2007; Knowlton et al., 2011). This is a striking range of phenotypes considering that neurons within the $\operatorname{Trpm} 8$ lineage make up $\sim 10 \%$ of the afferent population and suggests the existence of subpopulations that mediate distinct cold percepts (Xing et al., 2006; Madrid et al., 2009; McCoy et al., 2011). Ablated and $\operatorname{Trpm} 8^{-/-}$mice showed little to no noxious cold-evoked responses in our analysis of forepaw flinching and licking behaviors on a $0^{\circ} \mathrm{C}$ cold plate. These mice were also unresponsive to innocuous cooling in the evaporative cooling and two-temperature choice assays. Together, these data suggest the presence of TRPM8 in isolated and discrete innocuous cool fibers and cold nociceptors that signal these perceptually distinct temperatures centrally (Fig. 8). Additionally, the deficiencies in injury-evoked cold allodynia and lack of cooling-induced analgesia in $\operatorname{Trpm} 8^{-1-}$ and ablated mice further show the complexity of TRPM8 in cold signaling. These data suggest that cold nociceptors expressing TRPM8 become sensitized after injury and advocates for a population of cold sensors that provides pain relief under mild cooling. It will be interesting to determine whether these two seemingly paradoxical behaviors are coded by different cohorts within the overall TRPM8-expressing population of sensory neurons or whether this effect is attributable to signal processing at the level of the afferent, spinal cord, or beyond (Fig. 8).

Our data show that cold avoidance and thermal preference depends on both TRPM8 channels and neurons but that conditional ablation of TRPM8 afferents in the adult mouse leads to more profound deficits in cold behaviors compared with animals in which the trpm8 gene is rendered inactive embryonically. These results suggest the presence of TRPM8-independent transduction mechanisms in TRPM8 neurons, thereby providing cold sensitivity in the absence of TRPM8 channels. Other molecules have been linked to cold transduction, including TRPA1, the only other putative cold transducer (Story et al., 2003), and channels involved in signal propagation, such as Kv1 and two-pore (K2P) potassium channels that may work as excitability brakes (Madrid et al., 2009; Noël et al., 2009), and Nav1.8, which has biophysical properties that suggest that it functions as the lone impulse generator at cold temperatures (Zimmermann et al., 2007). Decreased expression of $\mathrm{K}^{+}$conductances is known to decrease cold thresholds, thereby increasing the number of cold-sensitive neurons and cold excitability during cold neuropathies (Madrid et al., 2009; Noël et al., 2009; Descoeur et al., 2011). Nav1.8 neurons play an important role in inflammatory pain and are needed for cold pain but not innocuous cold detection (Abrahamsen et al., 2008), and approximately one-half of menthol-sensitive DRG neurons express Nav1.8 (Shields et al., 2012). Consistent with these functional results, we find that $40.2 \pm 7.3 \%$ of GFPexpressing TRPM8 neurons in the Trpm $8^{G F P}$ mouse line are also immunoreactive for Nav1.8 ( $n=1859$ cells; R.P. and D.D.McK., unpublished observations). These results suggest that Nav1.8 may serve in noxious cold excitability in the absence of TRPM8 channels in Trpm $8^{-/-}$mice, but that when all TRPM8 neurons, including those expressing Nav1.8, are ablated, responses to noxious cold are attenuated. Last, recent evidence suggests that TRPA1 has a limited role, if any, in acute nonpathological cold sensation but is a key molecule in nociceptor hypersensitivity (Caspani and Heppenstall, 2009; del Camino et al., 2010; Knowlton et al., 2010). Thus, the incomplete abrogation of cold allodynia in $\operatorname{Trpm} 8^{-/-}$and ablated mice suggests that, although TRPM8 is important for cold hypersensitivity, additional molecular and cellular mechanisms also contribute significantly and account for the residual cold sensitivity we observe after injury in both TRPM8-deficient genotypes.

We find that ablated animals were phenotypically identical to $\operatorname{Trpm} 8^{-/-}$mice in many respects, including responses to evaporative cooling, cold-plate nocifensive behaviors, and cooling- 
induced analgesia. However, there were some significant differences between $\operatorname{Trpm} 8^{-1-}$ and ablated mice in the twotemperature choice assay and with neuropathic nerve injury. The latter is also intriguing because we did not observe any differences in inflammatory responses between the two genotypes. In rats, Proudfoot et al. (2006) reported altered TRPM8 expression in the CCI model, observing increased channel expression in A-fibers. Similarly, Su et al. (2011) presented evidence for increased TRPM8 protein expression in affected rat DRG by day 4 after injury, expression that peaked by day 10 , a time course that matches the evolution of cold allodynia. Because suitable antibodies detecting mouse TRPM8 are lacking, we used qPCR to determine whether TRPM8 transcript expression increased in ablated animals after injury but did not detect any expression. Therefore, it is unclear why ablated animals had increased cold sensitivity over $\operatorname{Trpm} 8^{-1-}$ mice in the CCI model, results that warrant additional investigation.

There were some striking differences between ablated mice and $\operatorname{Trpm} 8^{-/-}$animals in the two-temperature choice assay, with the former showing little to no ability to detect cold well into the noxious range. Indeed, it was not until test plate temperatures were lowered to $5^{\circ} \mathrm{C}$ that ablated mice showed any evidence of either cold avoidance or warm preference. As we and others have reported, $\operatorname{Trpm} 8^{-/-}$mice do show robust cold avoidance and warm preference starting at $15^{\circ} \mathrm{C}$ but never to levels observed in control animals (Bautista et al., 2007; Dhaka et al., 2007; Knowlton et al., 2010). These data suggest that, although TRPM8 is important for cold sensing in the noxious range, other mechanisms also contribute but intriguingly may be localized to TRPM8 neurons. As described above, Kv1, K2P, and Nav1.8 channels have been implicated in cold transduction. Differential expression of potassium channels are proposed to make coldand menthol-sensitive neurons amenable to activation by cold (Viana et al., 2002; Madrid et al., 2009) and segregate them into two loosely distinguished populations: those responding to innocuous cool temperatures having high TRPM8 and low Kv1 expression, whereas those activated by lower, noxious temperatures expressing low levels of TRPM8 and high levels of Kv1 channels (Madrid et al., 2009; McCoy et al., 2011). This model predicts that cold may be able to activate these cells even in the absence of TRPM8 activity (Viana et al., 2002; Madrid et al., 2009), a posit supported by our data. Last, mice in which neurons in the Nav1.8 lineage are ablated failed to respond on a $0^{\circ} \mathrm{C}$ cold plate but retained normal responses in the acetone evaporative cooling assay, results suggesting a cellular separation of innocuous cool and noxious cold sensing (Abrahamsen et al., 2008). These intriguing observations suggest that Nav1.8 (and perhaps $\mathrm{Kv1}$ and K2P) channels are differentially expressed in a subset of TRPM8 neurons and provides distinct neuronal populations the ability to respond to innocuous versus noxious cold.

\section{References}

Abrahamsen B, Zhao J, Asante CO, Cendan CM, Marsh S, Martinez-Barbera JP, Nassar MA, Dickenson AH, Wood JN (2008) The cell and molecular basis of mechanical, cold, and inflammatory pain. Science 321:702-705. CrossRef Medline

Babes A, Zorzon D, Reid G (2004) Two populations of cold-sensitive neurons in rat dorsal root ganglia and their modulation by nerve growth factor. Eur J Neurosci 20:2276-2282. CrossRef Medline

Basbaum AI, Bautista DM, Scherrer G, Julius D (2009) Cellular and molecular mechanisms of pain. Cell 139:267-284. CrossRef Medline

Bautista DM, Jordt SE, Nikai T, Tsuruda PR, Read AJ, Poblete J, Yamoah EN, Basbaum AI, Julius D (2006) TRPAl mediates the inflammatory actions of environmental irritants and proalgesic agents. Cell 124:1269-1282. CrossRef Medline
Bautista DM, Siemens J, Glazer JM, Tsuruda PR, Basbaum AI, Stucky CL, Jordt SE, Julius D (2007) The menthol receptor TRPM8 is the principal detector of environmental cold. Nature 448:204-208. CrossRef Medline

Bennett GJ, Xie YK (1988) A peripheral mononeuropathy in rat that produces disorders of pain sensation like those seen in man. Pain 33:87-107. CrossRef Medline

Bini G, Cruccu G, Hagbarth KE, Schady W, Torebjörk E (1984) Analgesic effect of vibration and cooling on pain induced by intraneural electrical stimulation. Pain 18:239-248. CrossRef Medline

Cain DM, Khasabov SG, Simone DA (2001) Response properties of mechanoreceptors and nociceptors in mouse glabrous skin: an in vivo study. J Neurophysiol 85:1561-1574. Medline

Caspani O, Heppenstall PA (2009) TRPA1 and cold transduction: an unresolved issue? J Gen Physiol 133:245-249. CrossRef Medline

Cavanaugh DJ, Lee H, Lo L, Shields SD, Zylka MJ, Basbaum AI, Anderson DJ (2009) Distinct subsets of unmyelinated primary sensory fibers mediate behavioral responses to noxious thermal and mechanical stimuli. Proc Natl Acad Sci U S A 106:9075-9080. CrossRef Medline

Chen H, Kohno K, Gong Q (2005) Conditional ablation of mature olfactory sensory neurons mediated by diphtheria toxin receptor. J Neurocytol 34:37-47. CrossRef Medline

Colburn RW, Lubin ML, Stone DJ Jr, Wang Y, Lawrence D, D'Andrea MR, Brandt MR, Liu Y, Flores CM, Qin N (2007) Attenuated cold sensitivity in TRPM8 null mice. Neuron 54:379-386. CrossRef Medline

Comaniciu D, Ramesh V, Meer P (2000) Real-time tracking of non-rigid objects using mean shift. Proceed 2000 IEEE Conf Comput Vision Pattern Recognition 2:142-149. CrossRef

Daniels RL, McKemy DD (2010) Design and construction of a twotemperature preference behavioral assay for undergraduate neuroscience laboratories. J Undergrad Neurosci Educ 9:A51-A56.

Daniels RL, Takashima Y, McKemy DD (2009) Activity of the neuronal cold sensor TRPM8 is regulated by phospholipase $\mathrm{C}$ via the phospholipid phosphoinositol 4,5-bisphosphate. J Biol Chem 284:1570-1582. CrossRef Medline

del Camino D, Murphy S, Heiry M, Barrett LB, Earley TJ, Cook CA, Petrus MJ, Zhao M, D’Amours M, Deering N, Brenner GJ, Costigan M, Hayward NJ, Chong JA, Fanger CM, Woolf CJ, Patapoutian A, Moran MM (2010) TRPA1 contributes to cold hypersensitivity. J Neurosci 30:15165-15174. CrossRef Medline

Descoeur J, Pereira V, Pizzoccaro A, Francois A, Ling B, Maffre V, Couette B, Busserolles J, Courteix C, Noel J, Lazdunski M, Eschalier A, Authier N, Bourinet E (2011) Oxaliplatin-induced cold hypersensitivity is due to remodelling of ion channel expression in nociceptors. EMBO Mol Med 3:266-278. CrossRef Medline

Dhaka A, Murray AN, Mathur J, Earley TJ, Petrus MJ, Patapoutian A (2007) TRPM8 is required for cold sensation in mice. Neuron 54:371-378. CrossRef Medline

Dhaka A, Earley TJ, Watson J, Patapoutian A (2008) Visualizing cold spots: TRPM8-expressing sensory neurons and their projections. J Neurosci 28:566-575. CrossRef Medline

Eccles R (1994) Menthol and related cooling compounds. J Pharm Pharmacol 46:618-630. CrossRef Medline

Garrison SR, Dietrich A, Stucky CL (2012) TRPC1 contributes to lighttouch sensation and mechanical responses in low-threshold cutaneous sensory neurons. J Neurophysiol 107:913-922. CrossRef Medline

Green BG, McAuliffe BL (2000) Menthol desensitization of capsaicin irritation. Evidence of a short-term anti-nociceptive effect. Physiol Behav 68: 631-639. CrossRef Medline

Hargreaves K, Dubner R, Brown F, Flores C, Joris J (1988) A new and sensitive method for measuring thermal nociception in cutaneous hyperalgesia. Pain 32:77-88. CrossRef Medline

Hayashi T, Kondo T, Ishimatsu M, Yamada S, Nakamura K, Matsuoka K, Akasu T (2009) Expression of the TRPM8-immunoreactivity in dorsal root ganglion neurons innervating the rat urinary bladder. Neurosci Res 65:245-251. CrossRef Medline

Hjerling-Leffler J, Alqatari M, Ernfors P, Koltzenburg M (2007) Emergence of functional sensory subtypes as defined by transient receptor potential channel expression. J Neurosci 27:2435-2443. CrossRef Medline

Jordt SE, McKemy DD, Julius D (2003) Lessons from peppers and peppermint: the molecular logic of thermosensation. Curr Opin Neurobiol 13: 487-492. CrossRef Medline

Jung S, Unutmaz D, Wong P, Sano G, De los Santos K, Sparwasser T, Wu S, 
Vuthoori S, Ko K, Zavala F, Pamer EG, Littman DR, Lang RA (2002) In vivo depletion of $\mathrm{CD} 11 \mathrm{c}(+)$ dendritic cells abrogates priming of CD8 $(+)$ $\mathrm{T}$ cells by exogenous cell-associated antigens. Immunity 17:211-220. CrossRef Medline

Knowlton WM, McKemy DD (2011) TRPM8: from cold to cancer, peppermint to pain. Curr Pharm Biotechnol 12:68-77. CrossRef Medline

Knowlton WM, Bifolck-Fisher A, Bautista DM, McKemy DD (2010) TRPM8, but not TRPA1, is required for neural and behavioral responses to acute noxious cold temperatures and cold-mimetics in vivo. Pain 150: 340-350. CrossRef Medline

Knowlton WM, Daniels RL, Palkar R, McCoy DD, McKemy DD (2011) Pharmacological blockade of TRPM8 ion channels alters cold and cold pain responses in mice. PLoS One 6:e25894. CrossRef Medline

Liu Y, Abdel Samad O, Zhang L, Duan B, Tong Q, Lopes C, Ji RR, Lowell BB, Ma Q (2010) VGLUT2-dependent glutamate release from nociceptors is required to sense pain and suppress itch. Neuron 68:543-556. CrossRef Medline

Ma Q (2010) Labeled lines meet and talk: population coding of somatic sensations. J Clin Invest 120:3773-3778. CrossRef Medline

Ma Q (2012) Population coding of somatic sensations. Neurosci Bull 28:9199. CrossRef Medline

Madrid R, de la Peña E, Donovan-Rodriguez T, Belmonte C, Viana F (2009) Variable threshold of trigeminal cold-thermosensitive neurons is determined by a balance between TRPM8 and Kv1 potassium channels. J Neurosci 29:3120-3131. CrossRef Medline

McCoy DD, Knowlton WM, McKemy DD (2011) Scraping through the ice: uncovering the role of TRPM8 in cold transduction. Am J Physiol Regul Integr Comp Physiol 300:R1278-R1287. CrossRef Medline

McKemy DD (2011) A spicy family tree: TRPV1 and its thermoceptive and nociceptive lineage. EMBO J 30:453-455. CrossRef Medline

McKemy DD, Neuhausser WM, Julius D (2002) Identification of a cold receptor reveals a general role for TRP channels in thermosensation. Nature 416:52-58. CrossRef Medline

Mishra SK, Hoon MA (2010) Ablation of TrpV1 neurons reveals their selective role in thermal pain sensation. Mol Cell Neurosci 43:157-163. CrossRef Medline

Mishra SK, Tisel SM, Orestes P, Bhangoo SK, Hoon MA (2011) TRPV1lineage neurons are required for thermal sensation. EMBO J 30:582-593. CrossRef Medline

Moqrich A, Hwang SW, Earley TJ, Petrus MJ, Murray AN, Spencer KS, Andahazy M, Story GM, Patapoutian A (2005) Impaired thermosensation in mice lacking TRPV3, a heat and camphor sensor in the skin. Science 307:1468-1472. CrossRef Medline

Noël J, Zimmermann K, Busserolles J, Deval E, Alloui A, Diochot S, Guy N, Borsotto M, Reeh P, Eschalier A, Lazdunski M (2009) The mechanoactivated $\mathrm{K}+$ channels TRAAK and TREK- 1 control both warm and cold perception. EMBO J 28:1308-1318. CrossRef Medline

Palmiter R (2001) Interrogation by toxin. Nat Biotechnol 19:731-732. CrossRef Medline

Peier AM, Moqrich A, Hergarden AC, Reeve AJ, Andersson DA, Story GM, Earley TJ, Dragoni I, McIntyre P, Bevan S, Patapoutian A (2002) A TRP channel that senses cold stimuli and menthol. Cell 108:705-715. CrossRef Medline

Perl ER (1996) Cutaneous polymodal receptors: characteristics and plasticity. Prog Brain Res 113:21-37. CrossRef Medline

Perl ER (2007) Ideas about pain, a historical view. Nat Rev Neurosci 8:7180. CrossRef Medline

Proudfoot CJ, Garry EM, Cottrell DF, Rosie R, Anderson H, Robertson DC,
Fleetwood-Walker SM, Mitchell R (2006) Analgesia mediated by the TRPM8 cold receptor in chronic neuropathic pain. Curr Biol 16:15911605. CrossRef Medline

Saito M, Iwawaki T, Taya C, Yonekawa H, Noda M, Inui Y, Mekada E, Kimata Y, Tsuru A, Kohno K (2001) Diphtheria toxin receptor-mediated conditional and targeted cell ablation in transgenic mice. Nat Biotechnol 19:746-750. CrossRef Medline

Shields SD, Ahn HS, Yang Y, Han C, Seal RP, Wood JN, Waxman SG, DibHajj SD (2012) $\mathrm{Na}(\mathrm{v}) 1.8$ expression is not restricted to nociceptors in mouse peripheral nervous system. Pain 153:2017-2030. CrossRef Medline

Simone DA, Kajander KC (1996) Excitation of rat cutaneous nociceptors by noxious cold. Neurosci Lett 213:53-56. CrossRef Medline

Simone DA, Kajander KC (1997) Responses of cutaneous A-fiber nociceptors to noxious cold. J Neurophysiol 77:2049-2060. Medline

Story GM, Peier AM, Reeve AJ, Eid SR, Mosbacher J, Hricik TR, Earley TJ, Hergarden AC, Andersson DA, Hwang SW, McIntyre P, Jegla T, Bevan S, Patapoutian A (2003) ANKTM1, a TRP-like channel expressed in nociceptive neurons, is activated by cold temperatures. Cell 112:819-829. CrossRef Medline

Su L, Wang C, Yu YH, Ren YY, Xie KL, Wang GL (2011) Role of TRPM8 in dorsal root ganglion in nerve injury-induced chronic pain. BMC Neurosci 12:120. CrossRef Medline

Suzuki SC, Furue H, Koga K, Jiang N, Nohmi M, Shimazaki Y, Katoh-Fukui Y, Yokoyama M, Yoshimura M, Takeichi M (2007) Cadherin-8 is required for the first relay synapses to receive functional inputs from primary sensory afferents for cold sensation. J Neurosci 27:3466-3476. CrossRef Medline

Takashima Y, Daniels RL, Knowlton W, Teng J, Liman ER, McKemy DD (2007) Diversity in the neural circuitry of cold sensing revealed by genetic axonal labeling of transient receptor potential melastatin 8 neurons. J Neurosci 27:14147-14157. CrossRef Medline

Takashima Y, Ma L, McKemy DD (2010) The development of peripheral cold neural circuits based on TRPM8 expression. Neuroscience 169:828 842. CrossRef Medline

Tse SY, Wei ET (1986) Inhibition of the shake response in rats by adenosine and 2-chloroadenosine. Psychopharmacology (Berl) 90:322-326. CrossRef

Viana F, de la Peña E, Belmonte C (2002) Specificity of cold thermotransduction is determined by differential ionic channel expression. Nat Neurosci 5:254-260. CrossRef Medline

Wei ET, Seid DA (1983) AG-3-5: a chemical producing sensations of cold. J Pharm Pharmacol 35:110-112. CrossRef Medline

Xing H, Ling J, Chen M, Gu JG (2006) Chemical and cold sensitivity of two distinct populations of TRPM8-expressing somatosensory neurons. J Neurophysiol 95:1221-1230. CrossRef Medline

Yoo YE, Ko CP (2011) Treatment with trichostatin A initiated after disease onset delays disease progression and increases survival in a mouse model of amyotrophic lateral sclerosis. Exp Neurol 231:147-159. CrossRef Medline

Zimmermann K, Leffler A, Babes A, Cendan CM, Carr RW, Kobayashi J, Nau C, Wood JN, Reeh PW (2007) Sensory neuron sodium channel Nav1.8 is essential for pain at low temperatures. Nature 447:855-858. CrossRef Medline

Zylka MJ, Rice FL, Anderson DJ (2005) Topographically distinct epidermal nociceptive circuits revealed by axonal tracers targeted to mrgprd. Neuron 45:17-25. CrossRef Medline 